\title{
A Ceia do Senhor Uma abordagem bíblica e de retorno às fontes
}

Orientador: Luiz Fernando Ribeiro Santana

Mestrando: Jonas dos Santos Ferreira

Área de Concentração: Teologia Sistemático-Pastoral

Linha de Pesquisa: Fé e Cultura

À luz da teologia bíblica e patrística, a presente pesquisa sobre o tema da Ceia do Senhor, busca nas suas origens as pistas para a compreensão de tal mistério, que constitui a fonte e o ápice de toda a vida cristã. O presente trabalho tem por objetivo colaborar com o crescimento da pesquisa no âmbito da teologia litúrgica, bem como, estimular e nutrir a vida do povo de Deus em sua experiência de fé por meio da vivência litúrgica, levando a compreensão mistagógia da Ceia do Senhor ao seio da comunidade eclesial.

Palavras-chave: Ceia do Senhor. Patrística. Teologia Bíblica. 